\title{
Shaping the Future Through Standardization
}

\section{Chapter 2 \\ The Standardisation of Natural Capital Accounting Methodologies}

\author{
Sylvain Maechler \\ (D) https://orcid.org/0000-0002-4107-2698 \\ University of Lausanne, Switzerland \\ Jean-Christophe Graz \\ (DD https://orcid.org/0000-0002-5583-8332 \\ University of Lausanne, Switzerland
}

\section{ABSTRACT}

The global ecological crisis has prompted the development of tools that try to redefine relations between business and nature, among them, natural capital accounting methodologies. The International Organization for Standardization (ISO) recently set standards on which these methodologies are based. Other actors, including the Big Four audit and accounting firms, developed their own methodologies outside the scope of ISO. This chapter examines why and how ISO developed natural capital accounting standards that are likely to compete with other methodologies. From the assumption that standards are not just technical, but also political instruments, it argues that they shape the future by creating power relations between actors within and outside ISO. The chapter suggests that these ISO standards aims at competing with first-movers' methodologies, in particular on the power implications resulting from transparency. It builds the argument on international political economy approaches to emphasise the link between technical specifications and power relations in contemporary capitalism. 


\section{INTRODUCTION}

This chapter explores two of the core topics addressed in this volume: standards as a tool for forecasting or shaping the future and the power relations in which groups of individuals exert their influence in standard-setting processes. To this end, the chapter focuses on the recent development of natural capital accounting methodologies and two new standards developed within the aegis of the International Organization for Standardization (ISO) for such methodologies: ISO 14007 (Environmental management: Determining environmental costs and benefits) and ISO 14008 (Monetary valuation of environmental impacts and related environmental aspects). These two standards aim at putting a price tag on environmental impacts resulting from the economic activities of organisations (ISO 14008) and supporting an environmental cost \& benefit analysis to relate such impacts to decision-making processes (ISO 14007). Martin Baxter, Chair of the technical committee 207, subcommittee 1, environmental management systems of ISO recently claimed in an interview that " $[\mathrm{t}]$ here is a growing drive towards valuing natural capital, as well as a need to undertake a monetary assessment of an organization's environmental aspects and impacts (...) having a set of standardized, harmonized methods becomes important" (Gould, 2018a). Those two standards are indeed conceived to complement one another by allowing "decision-makers to make informed choices in a way which is more likely to be economically and environmentally sustainable" (Gould, 2018a). While such topic is deeply technical, it also raised political issues both within and outside the working groups set for drafting the standards.

While the drafting process initiated by ISO in 2015 remains landmark, it is worth noting that a number of other bodies had pioneered initiatives on the issue of natural capital accounting before that. For instance, the Natural Capital Coalition and the Big Four audit and accounting firms, Deloitte, Ernst \& Young, KPMG and PricewaterhouseCoopers, (the Big Four). The first is a "global public-private partnership" (Andonova, 2017, p. 2) created in 2012 and supported by very large multinational companies (MNCs), non-governmental organisations (NGOs), states, academia and United Nations (UN) bodies. Such initiative aims at developing a "standardised framework for business to identify, measure and value their impacts and dependencies on natural capital" (Natural Capital Coalition, 2018b). To this end, they published in 2016 the Natural Capital Protocol that provides guidelines for natural capital accounting. While the Big Four are key stakeholders within this Coalition, they also have had a prominent role in the sustainability reporting, consulting and assurance market for many years (Villiers \& Maroun, 2018). Since 2010, they started to develop their own natural capital accounting methodologies to identify, quantify, value and compare the environmental impacts of MNCs. To this end, the Big Four often directly influence the development of future private 
regulations and standards (Fransen \& LeBaron, 2019). However, they refused to take part in the work of ISO, while representatives of the Natural Capital Coalition have only been passively involved.

As many other concepts or tools developed to face the ecological crisis, natural capital accounting is based on the environmental liberal paradigm of the so-called green economy that aims at making environmental and economic goals compatible (Bernstein, 2002; Bracking, 2015; Dempsey, 2016). Such a way of 'economicising nature' often relies on the 'valuation of ecosystem services', i.e. the valuation of the stocks and, most importantly, flows of benefits provided by nature. A number of techniques in environmental economics allow to put a monetary value on such benefits expected from nature. Ecosystem services valuation as standardised in ISO 14008 is only one component of natural capital accounting. Others are related to the development of environmental indicators and reporting techniques to make financial and environmental data directly comparable, so that a cost and benefit analysis can easily be undertaken. Ecosystem services is now an established and well defined concept (see: Boisvert, Méral, \& Froger, 2013; Boyd \& Banzhaf, 2007; Costanza et al., 2017). In contrast, natural capital accounting is still a new, vague and ill-defined concept with no agreed and shared definition. While it includes a heterogeneous set of tools and instruments, all of them aim at making financial and environmental data comparable and, therefore, prone to have a price. Natural capital accounting is thus defined as a tool that aims at measuring, valuing, recording, summarising and processing information about nature according to a predefined procedure. ${ }^{1}$ It includes monetary valuation (ISO 14008), cost \& benefit analysis (ISO 14007), disclosure through environmental reporting (which procedure is included in the two standards), and ideally an environmental action plan (provided by ISO 14001, the core standard of the ISO 14000 series).

The main objective of standards in natural capital accounting is to assess the risks and uncertainties arising directly or indirectly from the ecological crisis. As Maechler and colleagues recently underlined, "understanding, calculating or 'taming' uncertainty has become a matter of great concern of policy makers and scientific research in a world facing global, epochal and complex changes" (2019, p. 6). Against this background, the authors contend that natural capital accounting aims at reducing the complexity of the ecological crisis into objectifiable units of analysis. In other words, it aims at transforming uncertainties - something that is so complex that it is not susceptible to measurement - into quantitative and thus manageable risks. As a forecasting tool, natural capital accounting codifies such processes of uncertainty reduction.

This chapter examines why and how ISO set standards for natural capital accounting methodologies likely to compete with methodologies being developed by other actors and in other arenas. Drawing on scholarship in international political economy 
(IPE) that conceptualises the authority of standards and technical specifications in transnational environmental governance, we assume that standards are not just technical, but also political instruments (Graz, 2019; Katz-Rosene \& Paterson, 2018; Yates \& Murphy, 2019). We argue that the development of standards for natural capital accounting is thus likely to shape the future by transforming power relations within and outside standard-setting arenas. More specifically, these power relations build upon standardised science-based metrics deemed to support private policies in order to account for the past and anticipate the future state of 'nature'. Our findings suggest that the development of ISO 14007 \& ISO 14008 aims at competing with first-movers' methodologies, in particular on the power implications resulting from a transparent documentation and reporting.

The method used in this chapter builds on a case study based on qualitative material: semi-structured interviews with four members of the two working groups in charge of setting the standards in ISO including the two convenors of ISO 14007 \& ISO 14008 , as well as a participant observation of five days within the ISO Working Group 8 developing ISO 14007 in Beirut, Lebanon in March 2019. ${ }^{2}$ We also make use of other primary sources: formal documents from ISO including the two standards, informal documents provided by interviewees, and documents produced by the Big Four, the Natural Capital Coalition and other arenas developing such methodologies for natural capital accounting.

The aim of the chapter is to provide the reader with an overview of the issues related to the standard-setting process of tools for natural capital accounting methodologies. The first section of this paper examines the characteristics of standards and used for quantification: their purpose, the actors involved, and their power dimensions. The other three more empirical sections follow the same architecture regarding natural capital accounting and the standard-setting process of ISO 14007 \& ISO 14008 (purpose, actors, power). The chapter concludes by summarising the main results.

\section{CHARACTERISTICS OF STANDARDS}

\section{Purpose: The Forecasting Dimension of (Quantitative) Standards}

The global ecological crisis gave rise to many uncertainties related to the complexity of biophysical systems and unexpected consequences such as so-called 'feedback loops' effects. Economic actors have actively participated in the development of tools to reduce ecological uncertainties, including environmental indicators, models, risk management plans, sustainability assessments, accounting, and reporting. These tools often aim at representing the future state of nature in quantitative terms, in order 
to reduce undefined uncertainties into quantitative risks. Against this background, scholars have shown the importance of putting numbers on things in order to 'make things the same' (MacKenzie, 2009) or transforming "qualities into quantities, difference into magnitude" (Espeland \& Stevens, 1998, p. 315).

Yet, quantifying is not enough. A common way to think is needed such as the metric system so that everyone measures the same thing according to the same procedure. This is why standardisation allows to simplify previously complex things by creating "a vision of a world united" (Yates \& Murphy, 2019, p. 2). As Higgins and Larner (2010, p. 11), explain standards govern our everyday life. By shaping the future, they reduce the uncertainties arising from the many complexities of the world. Therefore, standards providing a procedure to quantify 'nature' - such as ISO 14007 \& ISO 14008 - are critical technical and political infrastructures to reduce the uncertainties of the ecological crisis.

Such dominant mode of governing the future through uncertainty reduction builds upon a specific instrumental rationality which attempts to respond to the systemic feature of risk in contemporary society (Beck, 1992). Indeed, capitalism has evolved in recent decades in such a way that risk "is now economically 'systemic, enveloping everyone'; and this is perhaps nowhere more apparent than in relation to nature and the risks ascribed to environmental transformation" (Christophers, 2018, pp. 331-332; J. Levy, 2005). Power (2004, pp. 10, 59) justifies the rise of the "risk management of everything" on the assumption that "individuals, organisations and societies have no choice but to organize in the face of uncertainty, to act 'as if' they know the risks they face". Risk management studies claim to provide tools for anticipating uncertainties. With a focus on the ability to control all uncertainties, they explore strategies for "managing the uncontrollable" (Kaplan \& Mikes, 2012, p. 11). Building on the example of corporate sustainability management and environmental standardisation, Sardá and Pogutz (2018, p. xxvii) note that "we need to learn not just to manage the possible or the improbable, but also to manage the impossible".

\section{Actors: Privatisation of International Standardisation}

The ecological crisis has prompted the rise of transnational private regulations such as environmental standards and certifications. They often provide a framework that shape MNCs' relation with nature. According to Murphy and Yates (2009, p. 2), ISO standards "may have had more impact than any of the UN-sponsored agreement of the 1990s". It has led Mazower (2013, p. 102) to describe ISO as "perhaps the most influential private organization in the contemporary world, with a vast and largely invisible influence over most aspects of how we live". Yet, these standards are often designed by the MNCs themselves, since they are based on 'multistakeholder' model, defined by Mena and Palazzo (2012, p. 528) as "private governance mechanisms 
involving corporations, civil society organizations, and sometimes other actors, such as governments, academia or unions, to cope with social and environmental challenges across industries and on a global scale".

IPE scholars emphasise the importance of private actors in shaping the rules of global political economy (Cutler, 2010), considering especially MNCs as "an intrinsic part of the fabric of environmental governance, as rule maker, and often rule enforcer" (D. L. Levy \& Newell, 2005, p. 330).The authority of private actors rests on an institutionalised form of power that is not exclusively conveyed by government institutions. It includes standards. Such involvement of private actors in the regulation of capitalism is nothing new, as Yates and Murphy recently underlined in a book exploring "the global standard setting since 1880". They point out that "private standardization has come to provide a critical infrastructure for the global economy" (2019, p. 2). In the environmental field, such an approach acknowledging the political role of MNCs is usually preferred by market liberals, since "it shifts the burden of regulation from the State to the firm, which can monitor environmental performance much more efficiently" (Clapp \& Dauvergne, 2011, p. 175). Dauvergne (2018) adopts a more critical stance by describing such tools as "eco-business" practices for communication and public relations. In the same vein, Bair and Palpacuer (2015, p. S3) argue that these instruments aim at promoting the ethical image of MNCs, by absorbing and anticipating criticisms, resistances, and contestations.

\section{Power: The Political Dimension of Standards}

Voluntary standards have always faced the difficult task of balancing opposing interests of producers and consumers while supporting technological innovations and broader welfare purposes. While consensus-based voluntary standards set procedures addressing such concerns, opposing commercial interests may be so great that socalled standards wars may preclude reaching the level of consensus required to agree on a common standard. Notorious cases in point include colour TV and videotapes, as well as early ISO attempt to define an Open System Interconnection (OSI) for what will later be known as the Internet (Yates \& Murphy, 2019). Producers may also align their interests in setting so-called consortia standards outside official arenas such as ISO, seen as too slow, burdensome and bureaucratic to find a timely solution for innovative technologies.

Standards can thus make whole new markets possible through what Egeydi (2000) calls 'gateway technologies' and shape entire business models as they can "become a condition for firms that wish to compete in the global marketplace" (Clapp, 1998, p. 299). According to Busch (2011, p. 13), standards are even part of "the technical, political, social, economic, and ethical infrastructure that constitutes 
human societies". He points out that international standards "shape not only the physical world around us but our social lives and even our very selves. [... They] are recipes by which we create realities" $(2011$, p. 2). Therefore, standardisation processes often create winners and losers and even the committee-based model whose procedure is based on the rule of consensus does not, however, prevent the most powerful actors from imposing their views (Yates \& Murphy, 2019). It is from this understanding that standards materialise a "non-conventional form of power in the organisation of contemporary capitalism" (2019, p. 8), and that Busch (2011, p. 33) stresses "the importance of power with respect to standards (...) reflected in the fact that the emergence of standards is almost invariably the result of conflict or disagreement".

Finally, standards are produced by a specialised knowledge usually called 'expertise', defined by Littoz-Monnet (2017, p. 2) as “a codified knowledge produced by specialist, and that is generally assumed to require skills and experience not possessed by professional administrators". There are, however, clear interconnections between politics and technical expertise, since the latter integrates scientific knowledge into a political decision-making process (Granjou, 2003). Therefore, standards are both technical and political, and they often blur the boundaries between what is political on the one hand, and what is a-political and purely technical on the other (Porter, 2005). As Mattli and Büthe (2011, p. 11) point out, "standards do not embody some objective truth or undisputed scientific wisdom professed by experts". In contrast, they are made by individual, driven by diverse and varied interests, and thus reflect and materialise power relations in their quest of regulation.

\section{PUROPOSE OF STANDARDS FOR NATURAL CAPITAL ACCOUNTING}

\section{Environmental Management Systems Standards}

ISO 14007 \& ISO 14008 standards are part of the ISO 14000 series, 'environmental management system standards'. They are "formal structured framework of policies, procedures, and practices to manage and reduce an organization's environmental impact" (Sardá \& Pogutz, 2018, p. 150), providing MNCs with a framework for the protection of the environment (Neves, Salgado, \& Beijo, 2017, p. 253). During the 1980s and 1990s, some MNCs established the first voluntary codes of conduct to define their relation with the environment and improve their environmental performance. It aimed at responding to several environmental catastrophes in the 1980s and to the 1992 Rio Earth Summit, in which industries played a key role by supporting the development of different 'voluntary' or 'best practice' codes (Clapp 
\& Dauvergne, 2011, p. 175; Sardá \& Pogutz, 2018, p. 148). Published in 1996, ISO 14001 was largely based on the British Standard 7750 of 1994. It was revised in 2015, to ensure that "the standards are [still] updated and relevant for the marketplace" (Ciravegna Martins da Fonseca, 2015, p. 43), and adapted to the latest trends in this domain. ISO 14001, the only certifiable standard of the ISO 14000 series, is often portrayed as the "Global Green Standard" (Heras-Saizarbitoria, 2017, p. 4), i.e. the "world's most used standard supporting the development of appropriate environmental policies and ensuring their implementation in all types of organizations" (Sardá \& Pogutz, 2018, p. 150). ISO 14001 aims at helping organisations to enhance their environmental performance, fulfil their compliance obligations and achieve their environmental objectives.

While Prakash and Potoski identify a number of framework conditions likely to help ISO 14001 to effectively induce "firms to pollute less and better comply with governmental regulations" (2006, p. xii), others have more doubts regarding the standards' effectiveness besides their use as a tool to compete in the global marketplace (Ciravegna Martins da Fonseca, 2015, p. 43). Whatever that may be, the importance of ISO 14001 in contemporary capitalism should be understood in the wake of the success of management systems standards such as ISO 9000 series first published in 1987. This management systems standard is intrinsically forward-looking, since its main principle is 'continual improvement', which needs to be measured and documented, ideally quantitatively. To achieve this goal, the other standards of the ISO 14000 series provide "practical tools for companies and organisations of all kinds looking to manage their environmental responsibilities" (ISO, 2018a). Thus, in contrast to certifiable standards such as ISO 14001, international standards ISO 14007 \& ISO 14008 cannot be used in certified conformity assessment. They remain, however, key tools designed to help organisations effectively identify, measure, describe and monitor their environmental impacts in quantitative terms.

\section{Natural Capital Accounting: an Academic Perspective}

As briefly explained in the introduction, natural capital accounting builds on the concept of 'ecosystem services', whose textbook definition is "the benefits human populations derive, directly or indirectly, from ecosystem functions" (Costanza et al., 1997, p. 253), but also on 'environmental accounting', which aims at providing a standardised measure of the sustainability of an organisation. In contrast to natural capital accounting, environmental accounting usually concerns public actors and provides accounts of the "environmental events which arise as a result of, and are intimately tied to, the economic actions of entities" (Bebbington \& Thomson, 2007, p. 42). 
Natural capital accounting is based on the leitmotiv that "we don't protect what we don't value" (Myers \& Reichert, 1997), following a narrative pointing out that "once nature and the service it provides are valued as market goods (...) nature will have a fighting chance" (Ervine, 2018, p. 159). Helm (2016, p. 4) argues that "refusing to price or place an economic value on nature risks environmental meltdown". Therefore, it is often portrayed as making "environmental concerns compatible with economic growth within predominantly capitalist markets and states" (Dempsey, 2016, p. 237). Such a view has been acknowledged by Costanza and his colleagues in a prominent study about the global valuation of ecosystem services, in which they claim that "the environment versus the economy is a false choice" (2014, p. 154). They point out that valuing ecosystem services is ultimately about raising awareness regarding the epochal decline of 'nature'.

But from a critical perspective, it relates to the fabrication of 'nature' as 'natural capital', through the integration of economic theory into environmental issues (Akerman, 2003; Sullivan, 2017). Against this background, Gómez-Baggethun and Ruiz-Pérez (2011) argue that monetary valuation of nature is the first step in a process of commodification of ecosystem services, currently promoted by dominant neoliberal discourses. Some point out that such "standardised sciencebased measurements" (Turnhout, Neves, \& Lijster, 2014, p. 581) subscribe to a depoliticisation of environmental governance and regulations, transforming political concerns into economic and technical solutions, or what Felli (2015, p. 1743) calls "the neoliberal depoliticisation of environmental policy". Market-based instruments for nature thus raise concern within the academic community about the "expansion of market valuation to spheres that were formerly unaffected by commerce" (Gómez-Baggethun \& Ruiz-Pérez, 2011,p. 619), and more broadly, about the "neoliberalisation of environmental regulation, management, and governance" (Castree, 2010, p. 1). However, such criticisms often build on an ill-defined or unclear definition of "neoliberalisation" of nature (Levrel \& Missemer, 2018), and Boisvert and her colleagues (2013, p. 1123) have underlined the "gap between discourse and practice" about market-based instruments for nature.

\section{Environmental Accounting: Tools Developed by Practitioners}

The power play raised by the most recent stage of development in natural accounting methodologies does not comes in a void. Back in 1993, the UN already set a System of Environmental-Economic Accounting, with the objective of becoming an "international statistical standard for environmental-economic accounting" (United Nations, 2014, p. vii). While the latest version of the methodology published in 2012 is viewed as having "the same authority and weight as the System of National Accounts" (Hamilton, 2016, p. 27), its scope remains in the domain of states' 
accounting systems rather than corporate accounting. At the intergovernmental level, the Organisation for Economic Cooperation and Development (OECD) also published several reports on this topic. The first was released in 2004. Entitled "Measuring Sustainable Development", it discussed the transformation of environmental units into monetary data (OECD, 2004). It was followed in 2006 by another one on "Cost-Benefit Analysis and the Environment" (OECD, 2006), whose main author was David Pearce, also involved in the so-called "Pearce Report". With the official name of "Blueprint for a Green Economy" (Pearce, Markandya, \& Barbier, 1989), the report gave rise to one of the first modern forms of environmental accounting and reporting. In 2018, the OECD released a new report providing an in-depth explanation of the latest methods and techniques on environmental accounting, focusing especially on environmental cost and benefit analysis (OECD, 2018).

While natural capital accounting informs decision-makers of the uncertainties that should be considered, there is always a part of such uncertainty that cannot be captured, so that there are clear limits in our capacities to anticipate the future (Maechler et al., 2019). However, this chapter contends that the ultimate aim of natural capital accounting - especially from a business perspective - is to make the future state of nature knowable, comparable and thus governable, by valuing both positive and negative externalities (i.e. 'impacts') of economic activities. ${ }^{3}$ The "True Value" methodology document of the audit and accounting firm KPMG points out that:

What executives need is a method to understand and quantify their externalities and the likelihood they will affect their company's earning capability and risk profile in the future (...) to help businesses combine financial earnings data with monetized externality data and quantify the likelihood and potential impact of the latter coming to influence the former. Ultimately, we need a standardized approach to measure societal value creation (KPMG International Cooperative, 2014, p. 5).

KPMG's methodology aims at measuring in monetary terms the "societal value creation", i.e. the environmental but also economic and social externalities. It allows to compare very different data into a common metric: money. This practice is part of the broader project of quantifying the relationships between capitalism - its actors and the world in which they operate. Focusing only on the environmental side, the PricewaterhouseCoopers methodology aims at the quantification and valuation of the firm's "environmental impacts associated with its operations and entire supply chain" (PricewaterhouseCoopers, 2015). To achieve this goal, their methodology represents nature as a 'liability' or an 'asset' into corporate extra-financial reporting of firms. Against this background, these natural capital accounting methodologies aim at transforming the heterogeneity of nature into objectifiable and commensurable units of analysis in quite the same way as transnational capitalism needs financial 
accounting standards to support capital accumulation. Since the Big Four are not only powerful actors in the accounting field but also key providers of audit, management consulting, financial and tax services for public and private entities, natural capital accounting could also soon be about the integration of nature into an international tax regime, involving clear implications regarding climate and biodiversity diplomacy and global political economy relations.

\section{What is the Purpose of ISO 14007 \& ISO $14008 ?$ The Challenge of Openness and Transparency}

As we have seen above, ISO 14007 \& ISO 14008 set standards for two key components of natural capital accounting methodologies. ISO 14008 provides a monetarised measure of an organisation's environmental impacts, building on the notion of 'ecosystem services'. ISO 14007 provides a standardised procedure to undertake an environmental cost and benefit analysis.

While ISO recognises a strong trend in monetary assessments (ISO, 2018b), transparency of such procedure is often very low. According to the convenor of ISO 14007, the Big Four are well known to have no interest in sharing their data and methodologies, and therefore leave other stakeholders uninformed on how they came to such or such monetary upshot. Although this behaviour is part of any companies' business model developing new tools to expand their market shares, it raises substantial concerns in a procedure whose underlying objective is precisely the disclosure of (environmental) information. This is all the more the case regarding an issue on which we should all have a say: the global ecological crisis. In this regard, both ISO 14008 and ISO 14007 underline the importance of transparent documentation and reporting during the all process of monetary valuation and cost-benefit analysis. The main purpose of ISO 14008 is indeed to "increase the awareness, comparability and transparency of the monetary valuation of environmental impacts and related environmental aspects. It demonstrates the benefits that monetary valuation methods offer to users. To achieve this purpose, standardised and transparent documentation of the methods, data and assumptions used to derive monetary values is essential" (ISO 14008). On its side, ISO 14007 provides "guidance on determining and documenting (...) environmental costs and benefits in a comprehensive and transparent way". It also helps "organisations disclose and exchange relevant information in a transparent way" (ISO 14007).

ISO 14008 builds on the concept ecosystem services, which is "useful to increase the understanding of natural capital and ecosystem services, their stocks \& flows and linkages" (Pandeya et al., 2016, p. 251). ISO 14008 monetary values the flows of ecosystem services, i.e. the environmental impacts. However, ISO 14008 makes a distinction between an environmental impact and aspect. It refers to the distinction 
Figure 1. ISO 14007 \& ISO 14008 (Inspired by a figure and related explanations provided by one member of the working groups)

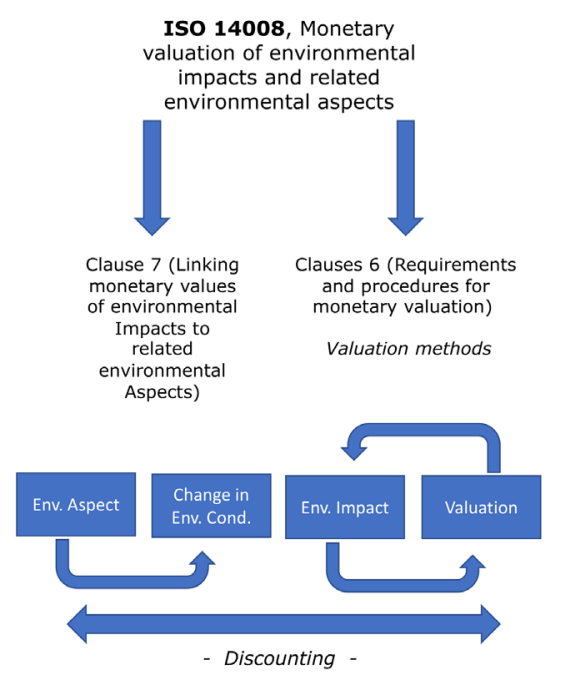

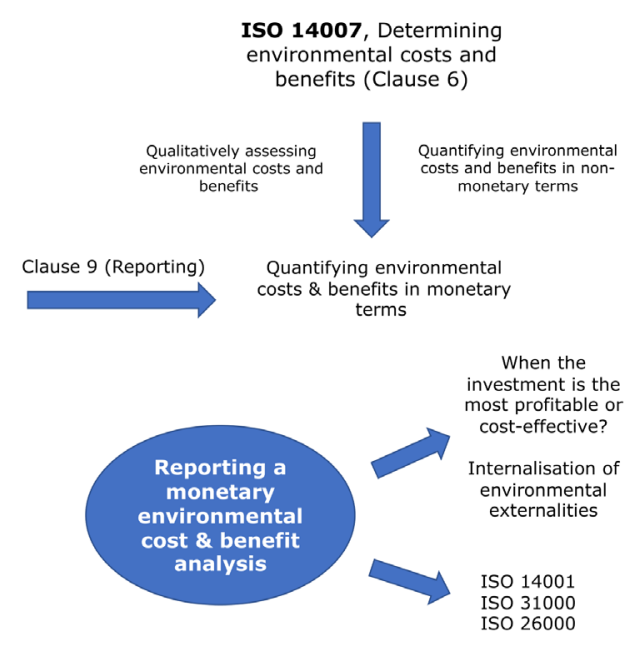

made in ISO 14001, which considers an environmental aspect as an element of the organisation's activities, products or services that can interact with the environment, or the 'interfaces' of the organisation with the environment. Environmental aspect is used as an analytical category to identify where the impact comes from in the operations of an organisation. For instance, an environmental aspect can provoke a change in environmental conditions, such as a change in the concentration of carbon dioxide in the air, which then impacts the natural environment and society. In ISO 14008, these impacts are valued in monetary terms according to clause 6 of the standard, 'requirements and procedures for monetary valuation' (see figure above), which provides different economic methods of valuation. It is also possible to skip these valuations techniques by directly linking valuation and environmental aspects through the so-called 'public averting cost method' based on targets at the administrative level. The value is then calculated according to the "cost of the last (most expensive) averting action to comply with a policy target", i.e. the marginal abatement cost (ISO 14008).

Therefore, ISO 14008 provides a monetary value from an environmental impact or directly from an environmental aspect. The reporting of the monetary valuation (clause 9) allows the further use of ISO 14007. ISO 14007 suggests that the cost and benefit analysis can also be expressed in qualitative way or in quantitative nonmonetary term (e.g. number of species loses, number of death/years). However, according to our interviewees, ISO 14007 has clearly been initially developed to be 
linked with ISO 14008 and thus expressed in quantitative monetary terms. Indeed, one of the objective of ISO 14007 is to clarify "why and how monetary valuation can be used and communicated as part of an existing environmental management approach or system" (ISO, 2019). As seen above, expressing different things in a common unit is the best way to reduce undefined uncertainties into manageable risks. Such possibility of direct comparison of environmental and financial data is in line with the standard itself, which aims at creating "a better understanding of issues such as the financial implications related to the environment of a given site, the organization as a whole, or along the organization's value chain" (ISO 14007).

Through the cost and benefit analysis, ISO 14007 helps to decide how much and especially when firms, states or 'society' as a whole have the greatest financial interest to reduce (or internalise) their environmental impacts (or externalities), so that the investment is the most profitable or cost-effective. Such a way to balance present costs against future benefits is a key issue in the prior phase, i.e. the monetary valuation. ISO 14008 thus provides guidelines to weight the monetary valuation according to different points in time ('discounting'). Discounting the future is a particular feature of uncertainty reduction in environmental economics. Natural capital accounting thus allows to compare future benefits (or costs) against any action that an organisation may take in the present. This means that these future costs and benefits have to be converted into a net present value. The usual assumptions made by 'experts' (in particular environmental economists) is that "the social or shadow price of a unit of consumption in the future is lower than the price of a unit of consumption today" (OECD, 2018, p. 197). ISO 14008 thus points out that "when the monetary values are applied to environmental impacts or aspects that occur at different points in time, discounting shall be performed".

Finally, as any other guidance standards, the first aim of ISO 14007 \& ISO 14008 is to objectify standards that require certification, in particular ISO 14001. But they can also be used in relation with other management standards, such as ISO 31000 (Risk management), to objectify environmental risks, or with other guidance standards, in particular ISO 26000 (Social responsibility), to define the relation between an organisation, the society and its environment, increasing the transparency and comparability of corporate social responsibility reporting. ISO 14007 \& ISO 14008 thus provide organisations with a 'toolbox' for transparent natural capital accounting.

\section{ACTORS OF NATURAL CAPITAL ACCOUNTING}

It is important to remind that ISO does not invent anything new. The convenor of ISO 14007 himself reminds that "ISO is only based on existing practices, follows 
what already exists". ${ }^{4}$ While we have seen above that the UN or the OECD have been involved in the field, their scope remains in the domain of states' environmental accounting systems rather than corporate natural capital accounting. Yet, other stakeholders have been involved in corporate natural capital accounting. Recently, The World Wide Fund for Nature, the World Bank, the World Business Council for Sustainable Development or the International Federation of Accountants all stressed the need to create a standardised procedure to translate environmental data into monetary units of analysis in order to face the global ecological crisis (The Association of Chartered Certified Accountants, Fauna \& Flora International, \& KPMG International Cooperative, 2012; WBCSD, 2011; WWF International, 2014). Various kinds of consulting firms, such as True Price, Trucost and eCountability, have been recently founded to offer natural capital accounting services to MNCs. As seen above, the Big Four are at the leading edge of the development of such methodology. Several years ago, Ernst \& Young already stressed that "it is time for our profession to play a leadership role in accounting for the relationship between the business world and the natural world" (Ernst \& Young, International Federation of Accountants, \& Natural Capital Coalition, 2014, p. 3). Moreover, many firms have already applied these methodologies, such as Kering, LafargeHolcim, Novo Nordisk or Novartis among others, always with the support of one of the Big Four.

Many of these actors including the Big Four meet within the Natural Capital Coalition - a platform founded in 2012, with its Natural Capital Protocol launched in 2016. This document provides a general guidance on how to measure impacts and dependencies on nature capital (Natural Capital Coalition, 2018b), but is still much too vague to be applied as a standard. According to Barker $(2019$, p. 70), the Natural Capital Protocol is not "a 'how to' guide for natural capital accounting; instead it is an eclectic mix of different approaches, applied in different ways to varying ends - more a 'take your pick' document than an accounting standard". The concrete activity of the Natural Capital Coalition consists in the promotion of such practices: it unites leading initiatives under "a common vision of a world that conserves and enhances the natural capital" (Natural Capital Coalition, 2018a). For this purpose, they organise presentations and meetings during which companies present their results and promote the usefulness of such an approach for their business. 


\section{POWER RELATIONS IN NATURAL CAPITAL ACCOUNTING STANDARDISATION}

\section{The Conflicts within ISO}

ISO 14007 \& ISO 14008 followed the same institutional path and have been developed by the same 'leading experts', raising similar debates, conflicts and disagreements. ISO 14008 was initially submitted to subcommittee 5, which sets standards in the field of life-cycle assessment (LCA). Bengt Steen, a chemical engineer who proposed the new item agenda of ISO 14008 also took part in the development of ISO 14040 on LCA within subcommittee 5 during the 1990s. He pointed out that "the good thing with subcommittee 5 is that it contains a lot of engineers, while other subcommittees contain more people from a management background". ${ }^{5}$ However, subcommittee 5 was opposed to monetary valuation practices and refused to host the future standard. In contrast, subcommittee 1 accepted to host it. This subcommittee is constituted of many environmental economists, usually committed to the cause of environmental and monetary valuation. What may seem anecdotal reflects the broader disagreements regarding the monetary valuation of nature between economists and engineers. In this regard, it is interesting to note that ISO 14008 underlines in its first paragraph that "using monetary valuation does not mean that money is the only metric of value" (ISO 14008). As a result of these issues related to the monetisation of the environment, the working groups developing both ISO 14007 \& ISO 14008 have been constituted of experts from two distinct disciplinary backgrounds: life-cycle assessment (engineering) and environmental economics. Even though the interviewees underlined that the working groups "agreed $90 \%$ of the time", such distinct disciplinary background raised particular debates on the issue of the discount rate: how to value the future in comparison to the present?

Indeed, the discount rate directly shape the future of business relation with nature, since a higher discount rate means that we should not reduce our environmental impacts too quickly on the assumption that "the economic cost to people today will be higher than the benefit of protecting people in the future" (Hickel, 2018). This is for instance what suggests William Nordhaus, laureate of the 2018 Nobel Memorial Prize in Economic Sciences, who hardly criticised the use of a low discount rate of $1.4 \%$ in the famous "Stern Review", a report on the economic costs of climate change (Nordhaus, 2007, p. 686; Stern, 2006). Against this background, while LCA uses a constant discount rate of $0 \%$, which means that future and present generations are valued equally (Hickel, 2018), environmental economists usually use a positive figure: they value the present more than the future. Our interviewees underlined that most disagreements within the working group concerned this single issue, which determine how the standard will forecast and anticipate the future management of 
the ecological crisis. They explained that if a fixed discount rate had been prescribed, no consensus would have been possible. ISO 14008 thus leaves the choice of the discount rate open, but asks for full transparency: "the process of discounting and the discount rates used, including when performed with a zero-discount rate, shall be documented and justified" (ISO 14008). This outcome has significant consequences regarding the implications that such emphasis on transparent documentation and reporting may have to be in conformity with the standard. However, not taking any decision regarding the discount rate to be applied can also be interpreted as a significant failure of ISO in a period in which societies have to make important intergenerational choices.

\section{ISO and the First-Movers}

ISO often faces 'first-movers' in its attempt to set a standard. In this regard, ISO tries to impose its own standards thanks to the legitimacy of the institution based on a multistakeholder consensus (Hahn \& Weidtmann, 2016). While states, academic scholars, consultants and experts from MNCs such as Veolia and Électricité de France all join in the standard-setting processes of ISO, the Big Four rather opt only for the Natural Capital Coalition. Since 2010, the Big Four published a full range of documents available online in which they describe their methodologies and illustrate them with case-studies that identify and quantify in financial terms MNC's environmental impacts. However, they do not share their full data and methodology because this is part of their business model. In contrast, these documents emphasize the relevance for business of taking account of nature capital and thus encourage the use of such tools. For instance, a document published by Ernst \& Young, the International Federation of Accountants and the Natural Capital Coalition called "Accounting for Natural Capital: The elephant in the boardroom" illustrates such 'selling strategy'. It underlines that "natural capital is still largely hidden from view and absent from the corporate narrative. This situation is no longer acceptable if organisation are to become truly sustainable" (Ernst \& Young et al., 2014, pp. 1, 3).

While representatives of the Natural Capital Coalition such as the Policy Director joined the working groups developing ISO 14007 and ISO 14008, their participation has remained limited to the firsts meetings. Indeed, they have been marginalised within the working groups. Working groups' members pointed out that representatives of the Natural Capital Coalition were not sufficiently familiar with the work of ISO, which is "democratic and formalised", in contrast to the Coalition's work. Second, they always made proposal to change the text, to bring in the definitions they use in the Natural Capital Protocol. Thus, they were seen by other members of the working groups as "entrepreneurs building their own agenda". ${ }^{8}$ According to the convenor of ISO 14007, "they were not involved because ISO was taking away attention by the 
market on their own things". More generally, he stressed the competition between different initiatives in this domain. ${ }^{9}$

This competition between different methodologies and potential standards resulted in the fact that none of the Big Four took part to the ISO working groups, despite an explicit invitation to do so from the convenor of ISO 14008. Such defect from the Big Four is striking, since a close relation usually exists between the accounting market and official standardisation bodies in the field of traditional accounting standards (Ramirez, 2013). Moreover, the Big Four are members of the national standardisation bodies like the British Standards Institution. Our analysis suggests that the transparency required by the standard is likely to have been a tipping point regarding the non-involvement of the Big Four. According to some views, they are wary of any standard that could modify their 'business model' regarding their own methodology, and they might only use the standards if they are in their favour. The convenor of ISO 14007 pointed out that "they make business with their own methodologies" and "are not interested that new standard are being developed". ${ }^{10}$ As briefly discussed above, this is fully understandable from a business perspective. However, transparency remains a core issue for the comparability of the data presented to both internal and external stakeholders. Without sufficient transparency, it is unlikely that natural capital accounting will achieve one of its main publicly recognised objectives: strengthening the 'social license to operate' by reducing the risks and uncertainties of business operations by making standardised information public for internal and external stakeholders alike.

There is thus clear evidence that such topic is not only about the techniques of environmental economics. Standardising natural capital accounting also raises power relations. This is not surprising, since it might also, in a near future, be about its integration into law, allowing authorities to engage ecological tax compliance procedures based on standardised accounting metrics. Against this background, this chapter provided an analysis in the wake of existing studies that ley emphasis on the underlying socio-political dimensions of the growing number of tools designed to integrate nature into an accounting and economic framework (Martinez-Alier, 2002; Purushothaman, Thomas, Abraham, \& Dhar, 2013).

\section{CONCLUSION}

This chapter has provided an analysis of recent developments on natural capital accounting and related standards likely to shape future relations between MNCs and nature. We saw that private actors and especially MNCs operating in the field are often directly involved in standardisation processes. Yet, this was not so much the case for ISO 14007 \& ISO 14008, as the main actors - the Big Four - did not take 
part in the working groups in charge of setting the standards. This is not surprising, considering the importance of their own methodologies in their business model. The first-movers could not impose their own standard and had no interest in the standard as drafted as it directly competed with their own proprietary methodology. Being opposed to ceding proprietary knowledge for the supposed common good of a standardised natural capital accounting methodology, they rather adopted a damage limitation strategy regarding the key issue threatening their business model - transparency. A similar strategy has been described by Graz and Hauert (2019, p. 179) regarding the largest players of the hospitality industry blocking any move towards labels and classification schemes such as stars.

Therefore, we have seen that standard-setting process is not only technical but also political, raising power relations both within and outside ISO. We have stressed the divergence of views at the level of ISO regarding the monetisation of nature, especially the issue of the discount rate at the level of the working groups. The latter reflects two distinct disciplinary backgrounds: experts of life-cycle assessment excluding the relevance of taking discount rate on-board on the one hand, and environmental economists debating among themselves about the rate of the discount on the other. Ultimately, such debate boils down to whether, and if so, how to value the future in comparison with the present on the balance sheet of a firm. Yet, the outcome of the negotiations leading to the international standard ISO 14008 is a double no, resulting from too much disagreement on the size of the discount rate. Despite what might look as a significant failure, the standard still provides guidance not only on valuation per se, but also on the importance of transparent documentation and reporting. It is especially from this perspective that these standards compete with other arenas, in particular the Natural Capital Coalition and the Big Four.

Finally, the role of natural capital accounting standards and quantitative measurement for shaping the future provide a quantitative procedure against which deciding how much and especially when firms, states or 'society' as a whole have the greatest financial interest to reduce their environmental impacts, so that the investment is the most profitable or cost-effective. This should encourage further research on how natural capital accounting and standards will shape our responses to the ecological crisis.

\section{ACKNOWLEDGMENT}

We had the opportunity to present a first draft of this paper at the 24th Conference of the European Academy for Standardisation (EURAS) at LUISS Guido Carli University of Rome. We are grateful to the participants for their questions and 
feedbacks. We also thank the reviewers for their valuable comments on previous drafts of the chapter.

This research received no specific grant from any funding agency in the public, commercial, or not-for-profit sectors.

\section{REFERENCES}

Akerman, M. (2003). What Does 'Natural Capital' Do? The Role of Metaphor in Economic Understanding of the Environment. Environmental Values, 12(4), 431-448. doi: $10.3197 / 096327103129341397$

Andonova, L. B. (2017). Governance entrepreneurs: International organizations and the rise of global public-private partnerships. Cambridge, UK: Cambridge University Press. doi:10.1017/9781316694015

Bair, J., \& Palpacuer, F. (2015). CSR beyond the corporation: Contested governance in global value chains. Global Networks, 15(1), S1-S19. doi:10.1111/glob.12085

Barker, R. (2019). Corporate natural capital accounting. Oxford Review of Economic Policy, 35(1), 68-87. doi:10.1093/oxrep/gry031

Bebbington, J., \& Thomson, I. (2007). Social and Environmental Accounting, Auditing, and Reporting: A Potential Source of Organisational Risk Governance? Environment and Planning. C, Government \& Policy, 25(1), 38-55. doi:10.1068/ $\mathrm{c0616j}$

Beck, U. (1992). Risk Society: Towards a New Modernity. London: SAGE.

Bernstein,S.(2002).LiberalEnvironmentalismand GlobalEnvironmentalGovernance. Global Environmental Politics, 2(3), 1-16. doi:10.1162/152638002320310509

Boisvert, V., Méral, P., \& Froger, G. (2013). Market-Based Instruments for Ecosystem Services: Institutional Innovation or Renovation? Society \& Natural Resources, 26(10), 1122-1136. doi:10.1080/08941920.2013.820815

Boyd, J., \& Banzhaf, S. (2007). What are ecosystem services? The need for standardized environmental accounting units. Ecological Economics, 63(2-3), 616-626. doi:10.1016/j.ecolecon.2007.01.002

Bracking, S. (2015). Performativity in the Green Economy: How far does climate finance create a fictive economy? Third World Quarterly, 36(12), 2337-2357. doi $: 10.1080 / 01436597.2015 .1086263$ 
Busch, L. (2011). Standards: Recipes for Reality. Cambridge, MA: The MIT Press. doi:10.7551/mitpress/8962.001.0001

Castree, N. (2010). Neoliberalism and the biophysical environment: A synthesis and evaluation of the research. Environment and Society: Advances in Research, 1(1), 5-45. doi:10.3167/ares.2010.010102

Christophers, B. (2018). Risking value theory in the political economy of finance and nature. Progress in Human Geography, 42(3), 330-349. doi:10.1177/0309132516679268

Ciravegna Martins da Fonseca, L. M. (2015). ISO 14001:2015: An improved tool for sustainability. Journal of Industrial Engineering and Management, 8(1), 37-50. doi:10.3926/jiem.1298

Clapp, J. (1998). The Privatization of Global Environmental Governance: ISO 14000 and the Developing World. Global Governance, 4(3), 295-316. doi:10.1163/19426720-00403004

Clapp, J., \& Dauvergne, P. (2011). Paths to a Green World - The Political Economy of the Global Environment. Cambridge, MA: MIT Press.

Costanza, R., d'Arge, R., de Groot, R., Farber, S., Grasso, M., Hannon, B., ... van den Belt, M. (1997). The value of the world's ecosystem services and natural capital. Nature, 387(6630), 253-260. doi:10.1038/387253a0

Costanza, R., de Groot, R., Braat, L., Kubiszewski, I., Fioramonti, L., Sutton, P., ... Grasso, M. (2017). Twenty years of ecosystem services: How far have we come and how far do we still need to go? Ecosystem Services, 28, 1-16. doi:10.1016/j. ecoser.2017.09.008

Costanza, R., de Groot, R., Sutton, P., van derPloeg, S., Anderson, S. J., Kubiszewski, I., ... Turner, R. K. (2014). Changes in the global value of ecosystem services. Global Environmental Change, 26, 152-158. doi:10.1016/j.gloenvcha.2014.04.002

Cutler, A. C. (2010). The legitimacy of private transnational governance: Experts and the transnational market for force. Socio-economic Review, 8(1), 157-185. doi:10.1093er/mwp027

Dauvergne, P. (2018). Will Big Business Destroy Our Planet? Cambridge, UK: Polity. de Villiers, C., \& Maroun, W. (Eds.). (2018). Sustainability Accounting and Integrated Reporting. London: Routledge. 
Dempsey, J. (2016). Enterprising Nature: Economics, Markets, and Finance in Global Biodiversity Politics. Chichester, UK: Wiley. doi:10.1002/9781118640517

Egyedi, T. M. (2000). The Standardised Container: Gateway Technologies in Cargo Transport. Homo Oeconomicus, 17, 231-262.

Ernst \& Young, International Federation of Accountants, \& Natural Capital Coalition. (2014). Accounting for Natural Capital - The elephant in the boardroom. Retrieved from Chartered Institute of Management Accountants website: https://www.ey.com/ Publication/vwLUAssets/Accounting-for-natural-capital/\$File/EY-Accounting-fornatural-capital.pdf

Ervine, K. (2018). Carbon. Cambridge, MA: Polity.

Espeland, W. N., \& Stevens, M. L. (1998). Commensuration as a Social Process. Annual Review of Sociology, 24(1), 313-343. doi:10.1146/annurev.soc.24.1.313

Felli, R. (2015). Environment, not planning: The neoliberal depoliticisation of environmental policy by means of emissions trading. Environmental Politics, 24(5), 641-660. doi:10.1080/09644016.2015.1051323

Fransen, L., \& LeBaron, G. (2019). Big audit firms as regulatory intermediaries in transnational labor governance. Regulation \& Governance, 13(2), 260-279. doi:10.1111/rego.12224

Gómez-Baggethun, E., \& Ruiz-Pérez, M. (2011). Economic valuation and the commodification of ecosystem services. Progress in Physical Geography, 35(5), 613-628. doi:10.1177/0309133311421708

Gould, R. (2018, May 8). The secret to unlocking green finance. Retrieved 16 April 2019, from ISO website: http://www.iso.org/cms/render/live/en/sites/isoorg/contents/ news/2018/05/Ref2287.html

Granjou, C. (2003). L'expertise scientifique à destination politique. Cahiers Internationaux de Sociologie, 1(114), 175-183. doi:10.3917/cis.114.0175

Graz, J.-C. (2019). The Power of Standards: Hybrid Authority and the Globalisation of Services. Cambridge, UK: Cambridge University Press. doi:10.1017/9781108759038

Graz, J.-C., \& Hauert, C. (2019). Translating Technical Diplomacy: The Participation of Civil Society Organisations in International Standardisation. Global Society, 33(2), 163-183. doi:10.1080/13600826.2019.1567476 
Hahn, R., \& Weidtmann, C. (2016). Transnational Governance, Deliberative Democracy, and the Legitimacy of ISO 26000: Analyzing the Case of a Global Multistakeholder Process. Business \& Society, 55(1), 90-129. doi:10.1177/0007650312462666

Hamilton, K. (2016). Measuring Sustainability in the UN System of EnvironmentalEconomic Accounting. Environmental and Resource Economics, 64(1), 25-36. doi:10.100710640-015-9924-y

Helm, D. (2016). Natural Capital: Valuing the Planet. New Haven, CT: Yale University Press.

Heras-Saizarbitoria, I. (Ed.). (2017). ISO 9001, ISO 14001, and New Management Standards. New York: Springer.

Hickel, J. (2018). The Nobel Prize for Climate Catastrophe. Retrieved from https:// foreignpolicy.com/2018/12/06/the-nobel-prize-for-climate-catastrophe/

Higgins, V., \& Larner, W. (Eds.). (2010). Calculating the Social: Standards and the Reconfiguration of Governing. New York: Palgrave Macmillan. doi:10.1057/9780230289673

International, W. W. F. (2014). Accounting for Natural Capital in EU Policy DecisionMaking: A WWF background paper on policy developments. Retrieved from http:// wwf.panda.org/?uNewsID=222134

ISO. (2018a). ISO 14000 Environmental management. Retrieved from ISO website: http://www.iso.org/cms/render/live/en/sites/isoorg/home/standards/popularstandards/iso-14000-environmental-manageme.html

ISO. (2018b). ISO 14008-Monetary Valuation of environmental impacts and related environmental aspects. Retrieved from https://committee.iso.org/sites/tc207sc1/ home/projects/ongoing/iso-14008.html

ISO. (2019). ISO 14008:2019 has now been published! Retrieved from ISO/TC 207/ SC1 website: https://committee.iso.org/sites/tc207sc1/home/news/content-left-area/ news-and-updates/iso-140082019-has-now-been-publi.html

Kaplan, R. S., \& Mikes, A. (2012). Managing Risks: A New Framework. Harvard Business Review.

Katz-Rosene, R., \& Paterson, M. (2018). Thinking Ecologically About the Global Political Economy. New York: Routledge. doi:10.4324/9781315677835 
KPMG International Cooperative. (2014). A New Vision of Value. Connecting corporate and societal value creation. Amstelveen: KPMG.

Levrel, H., \& Missemer, A. (2018). La mise en économie de la nature, contrepoints historiques et contemporains. Revue Economique, 69, 120-146.

Levy, D. L., \& Newell, P. (2005). The Business of Global Environmental Governance. Cambridge, MA: MIT Press.

Levy, J. (2005). Freaks of Fortune: The Emerging World of Capitalism and Risk in America. Cambridge, MA: Harvard University Press.

Littoz-Monnet, A. (2017). Production and uses of expertise by international bureaucracies. In A. Littoz-Monnet, The Politics of Expertise in International Organizations: How International Bureaucracies Produce and Mobilize Knowledge (pp. 1-18). New York: Routledge. doi:10.4324/9781315542386-1

MacKenzie, D. (2009). Making things the same: Gases, emission rights and the politics of carbon markets. Accounting, Organizations and Society, 34(3), 440-455. doi:10.1016/j.aos.2008.02.004

Maechler, S., Furrer, E., Lunghi, E., Monthoux, M., Yousefzai, C., \& Graz, J.-C. (2019). Substituting risk for uncertainty. Where are the limits and how to face them? Les Cahiers de l'IEP, (73), 1-28.

Martinez-Alier, J. (2002). The Environmentalism of the Poor: A Study of Ecological Conflicts and Valuation. Cheltenham, UK: Edward Elgar Publishing. doi: $10.4337 / 9781843765486$

Mattli, W., \& Buthe, T. (2011). The New Global Rulers. Princeton, NJ: Princeton University Press.

Mazower, M. (2013). Governing the World: The History of an Idea, 1815 to the Present. New York: Penguin Books.

Mena, S., \& Palazzo, G. (2012). Input and Output Legitimacy of Multi-Stakeholder Initiatives. Business Ethics Quarterly, 22(3), 527-556. doi:10.5840/beq201222333

Myers, J. P., \& Reichert, J. S. (1997). Perspective in nature's services. In G. Daily (Ed.), Nature's Services: Societal Dependence on Natural Ecosystems (pp. xvii-xx). Washington, DC: Island Press.

Natural Capital Coalition. (2018a). Natural Capital Coalition I Coalition Organizations. Retrieved from https://naturalcapitalcoalition.org/who/coalitionorganizations/ 
Natural Capital Coalition. (2018b). Natural Capital Coalition | Protocol. Retrieved from https://naturalcapitalcoalition.org/protocol/

Neves, F. de O., Salgado, E. G., \& Beijo, L. A. (2017). Analysis of the Environmental Management System based on ISO 14001 on the American continent. Journal of Environmental Management, 199, 251-262. doi:10.1016/j.jenvman.2017.05.049 PMID:28552409

Nordhaus, W. D. (2007). A Review of the Stern Review on the Economics of Climate Change. Journal of Economic Literature, 45(3), 686-702. doi:10.1257/jel.45.3.686 PMID:17626869

OECD. (2004). Measuring Sustainable Development: Integrated Economic, Environmental and Social Frameworks. Retrieved from: https://www.oecd-ilibrary. org/environment/measuring-sustainable-development_9789264020139-en

OECD. (2006). Cost-Benefit Analysis and the Environment: Recent Developments. Retrieved from http://www.oecd.org/greengrowth/tools-evaluation/cost-benefitana lysisandtheenvironmentrecentdevelopments2006.htm

OECD. (2018). Cost-Benefit Analysis and the Environment: Further Developments and Policy Use. Retrieved from https://www.oecd.org/governance/cost-benefitanalysis-and-the-environment-9789264085169-en.htm

Pandeya, B., Buytaert, W., Zulkafli, Z., Karpouzoglou, T., Mao, F., \& Hannah, D. M. (2016). A comparative analysis of ecosystem services valuation approaches for application at the local scale and in data scarce regions. Ecosystem Services, 22, 250-259. doi:10.1016/j.ecoser.2016.10.015

Pearce, D. W., Markandya, A., \& Barbier, E. B. (1989). Blueprint for a Green Economy. London: Earthscan.

Porter, T. (2005). Private Authority, Technical Authority, and the Globalization of Accounting Standards. Business and Politics, 7(3), 1-30. doi:10.2202/14693569.1138

Power, M.(2004). The RiskManagementofEverything.London:Demos. doi:10.1108/ eb023001

Prakash, A., \& Potoski, M. (2006). The Voluntary Environmentalists: Green Clubs, ISO 14001, and Voluntary Environmental Regulations. Cambridge, UK: Cambridge University Press. doi:10.1017/CBO9780511617683

PricewaterhouseCoopers. (2015). Valuing corporate environmental impacts. London: PwC. 
Purushothaman, S., Thomas, B., Abraham, R., \& Dhar, U. (2013). Beyond money metrics: Alternative approaches to conceptualising and assessing ecosystem services. Conservation \& Society, 11(4), 321. doi:10.4103/0972-4923.125739

Ramirez, C. (2013). Normalisation des services marchands ou marchandisation des normes. In J.-C. Graz \& N. Niang, Services sans frontières (pp. 223-252). Paris: Presses de Sciences Po.

Sardá, R., \& Pogutz, S. (2018). Corporate Sustainability in the 21st Century: Increasing the Resilience of Social-Ecological Systems. New York: Routledge. doi:10.4324/9781315180908

Stern, N. (2006). Stern Review: The Economics of Climate Change. London: Stationery Office.

Sullivan, S. (2017). Making nature investable: From legibility to leverageability in fabricating 'nature' as 'natural capital'. Science \& Technology Studies, 20, 1-30.

The Association of Chartered Certified Accountants, Fauna \& Flora International, \& KPMG International Cooperative. (2012). Is natural capital a material issue? Executive summary. Retrieved from http://www.acca.ee/content/dam/acca/global/ PDF-technical/environmental-publications/natural-capital-summary.pdf

Turnhout, E., Neves, K., \& de Lijster, E. (2014). 'Measurementality' in Biodiversity Governance: Knowledge, Transparency, and the Intergovernmental Science-Policy Platform on Biodiversity and Ecosystem Services (Ipbes). Environment and Planning A. Economy and Space, 46(3), 581-597.

United Nations. (Ed.). (2014). System of environmental-economic accounting 2012: Central framework. New York: United Nations.

WBCSD. (2011). Guide to corporate ecosystem valuation: A framework for improving corporate decision-making. Geneva: World Business Council for Sustainable Development (WBCSD).

Yates, J., \& Murphy, C. N. (2009). The International Organizationfor Standardization. London: Routledge.

Yates, J., \& Murphy, C. N. (2019). Engineering Rules. Global Standard Setting since 1880. Baltimore, MD: Johns Hopkins University Press. 


\section{KEY TERMS AND DEFINITIONS}

Big Four Audit and Accounting Firms: The four largest and most powerful world companies offering accounting but also audit, management consulting, financial or legal services for public and private entities.

Ecological Crisis: The radical, systemic, and complex changes of ecological systems due to human interferences with the biosphere.

Environmental Accounting: A set of rules and categories designed to measure nature in monetary or biophysical units.

International Organization for Standardization (ISO): The non-governmental organisation in charge of setting voluntary international standards with a membership of standardisation bodies from 164 countries.

International Political Economy: A field of study closely related to the discipline of international relations exploring the relations between the political and economic sphere at the global level.

Natural Capital: An extension the economic notion of capital to natural resources and that is supposed to underpin all other forms of capital, i.e. human, technological manufactured and financial capital.

Natural Capital Accounting: A tool that aims at measuring, recording, summarising, and processing information about nature according to a predefined procedure. It includes monetary valuation, environmental reporting, cost and benefit analysis and ideally an environmental action plan or strategy.

Power: The individual or collective ability to influence the outcome of a process, whether voluntarily or not (e.g. the setting of a new standard).

Standard: A voluntary technical specification explicitly documented and published as tools for the organisation of production and exchange of goods and services.

Transnational Private Governance: A form of cooperation between state and non-state across borders in order to establish rules and standards of behaviour.

\section{ENDNOTES}

1 See also the online recording of the webinar of 'We Value Nature' on "an introduction to natural capital", $3^{\text {rd }}$ October 2019. https://wbcsd.zoom.us/ recording/play/ENLNLPhSfAWpNI7cCFc5w3J_7GQXaDVq69s8EIwFyR0 4gyeDFZ42Qm2DZUEKYHj1? continueMode=true

2 ISO/TC 207/SC 1/WG 8 "Guidelines on determining environmental costs and benefits". 
3 Externalities were defined by Coase as "actions of business firms which have harmful effects on others”. See: Coase, R. (1960). The Problem of Social Cost. The Journal of Law \& Economics, 3, 1-44.

4 Interview with the Convenor of ISO 14007, Aarau, Switzerland (22 January, 2019).

$5 \quad$ Skype Interview with the Convenor of ISO 14008 (26 November, 2018).

6 Interview with a member of the two ISO working groups, Geneva, Switzerland (26 November, 2018).

$7 \quad$ Skype Interview with the Convenor of ISO 14008 (26 November 2018).

$8 \quad$ Skype Interview with the Convenor of ISO 14008 (26 November 2018).

9 Interview with the Convenor of ISO 14007, Aarau, Switzerland (22 January, 2019).

10 Interview with the Convenor of ISO 14007, Aarau, Switzerland (22 January, 2019). 